\title{
Marx for His Times
}

This is an Original Manuscript of a review article published by Taylor \& Francis in Global Intellectual History on 19 July 2017 available at

http://www.tandfonline.com/doi/full/10.1080/23801883.2017.1354968.

At the beginning of a lecture course on Aristotle, Martin Heidegger remarked: 'Regarding the personality of a philosopher, our only interest is that he was born at a certain time, that he worked, and that he died'. ${ }^{1}$ It is easy to sympathize with this sentiment, if not fully to endorse it. What interests us about influential thinkers are their works, and those works can be read, interpreted, and used without knowing anything about the lives of those who produced them. As Gareth Stedman Jones puts it in his new biography of Marx: 'However interesting Marx's life was, his enduring importance derives from the impact of the ideas he developed in a remarkable series of texts'. ${ }^{2}$ Nonetheless, dozens of biographies of Marx have been written. This is in part because - unlike, say, Kant - Marx led a varied and eventful life: he was a political organizer and activist as well as a writer, and was to a greater or lesser extent involved in some of the most significant events of the nineteenth century, including the 1848 revolutions, the 1871 Paris Commune, and the founding and dissolution of the First International. Even writers unsympathetic to Marx's ideas have characterized him as a 'great man'. ${ }^{3}$ Yet, it is not simply an interest in Marx's life that has motivated his biographers: given his interests and activities, the life of Marx is inseparable from the politics of Marx, and to write his biography is necessarily to enter into a political debate. This is true even - and perhaps especially - of those who have sought to 'humanise' their subject by 'rediscover[ing] Karl Marx the man'. ${ }^{4}$ Early biographers more or less openly sought to promote Marxism by glorifying the man behind the movement. One of the first, Franz Mehring of the SPD and then the KPD, set out 'to present him in all his powerful and rugged greatness' and names Marx 'the greatest genius of them of all' amongst the geniuses of the $19^{\text {th }}$ century. ${ }^{5}$ (For all that, Mehring did not produce a simple hagiography, and his Karl Marx is still well worth reading.) Conversely, there are those who have sought to undermine the ideology by discrediting the man. While some biographers have resorted to character assassination, ${ }^{6}$ a subtler approach has been to historicise Marx's life and works, placing them safely in their own times. This approach relieves Marx of blame for twentieth-century horrors committed in his name, but it simultaneously limits his relevance for the twenty-first century. The most recent example of this genre is Jonathan Sperber's Karl Marx, which argues that ' $[\mathrm{t}]$ he view of Marx as a contemporary whose ideas are shaping the modern world has run its course and it is time for a new understanding of him as a figure of a past historical epoch, one increasingly distant from our own'. 
Stedman Jones's book has something in common with Sperber's, in that it declares that its aim 'is to put Marx back in his nineteenth century surroundings'. ${ }^{8}$ But Sperber does not show much interest in (or understanding of) Marx's ideas: his aim in placing Marx in his nineteenth-century context is essentially to demonstrate the obsolescence of his work. In contrast, Stedman Jones declares that 'I have decided to pay as much attention to Marx's thought as to his life', and he makes a claim for the continued - though limited - significance of that thought. ${ }^{9}$ His approach, very broadly speaking, is that of a Cambridge School historian of ideas: to understand Marx's work, we must reconstruct the context(s) within which he wrote and appreciate that 'whether as philosopher, political theorist or critic of political economy, his writings were intended as interventions in already existing fields of discourse ${ }^{10}{ }^{10}$ In one sense this approach is especially fitting for Marx, who viewed his own writings precisely as interventions intended to change the world: placing Marx in his political context, as Stedman Jones does, allows us to see him as a militant and revolutionary and not merely an author or philosopher; an active participant in the struggles of his day and not merely a passive observer. ${ }^{11}$ On the other hand, it presents Marx as a revolutionary of the nineteenth century: one of the effects of putting Marx in his context is to emphasize the distance of that context - and hence of Marx himself - from our own.

Hence, notwithstanding Stedman Jones's insistence on Marx's 'enduring importance', his book is also an attempt to deflate Marx's reputation. This is attempted not only by returning Marx to his own times, but also by the repeated contention that Marx himself was a poor interpreter of those times. Whilst Marx is praised for his achievements, those achievements are presented as something like inadvertent by-products of his work (for example, helping to create a new language of social democracy, or contributing to the founding of social history as we know it today). ${ }^{12}$ Stedman Jones's book, pulling together an astonishing range of sources, offers a superb overview of the political context of Marx's work and to that extent it makes an important contribution to our understanding of Marx's life and times. But I found his expositions of Marx's writings much less insightful and convincing.

Like many of his predecessors, Stedman Jones seems overeager to paint Marx in a poor light. For example, much is made of the alleged anti-Semitism of 'On the Jewish Question'. ${ }^{13}$ This is a legitimate (and common) interpretation of the text, but it is also narrow and unbalanced: others have argued that Marx's use of anti-Semitic tropes must be understood ironically, and after reading Stedman Jones an uninformed reader would not necessarily appreciate that Marx was defending the rights of Jews to emancipation (against Bruno Bauer, who later became an explicit anti-Semite). ${ }^{14}$

A tendency to see the worst in Marx colours Stedman Jones's view of Marx's work as whole as much as his interpretations of individual texts. He refuses (rightly, in my view) to impose an 
overall coherence on Marx's oeuvre and instead tends to emphasise breaks and discontinuities. But whereas we might attribute those discontinuities to a process of development and improvement, Stedman Jones portrays them as inconsistencies and weaknesses. To take an example: in the Grundrisse Marx discusses the tendency of the rate of profit to fall in terms of the 'explosions, cataclysms, crises' that push capitalism towards its 'violent overthrow'. ${ }^{15}$ In contrast, in Capital Volume Three (that is, in the manuscripts of the 1860s that were later edited and published as Capital Volume Three) his focus shifts to those influences that counteract the tendency, and he argues that crises can even benefit capitalism (by resolving existing contradictions and 'for a time restor[ing] the disturbed equilibrium'). ${ }^{16}$ For Stedman Jones, this shift is indicative of Marx's increasing 'doubts' concerning his economic theories and ultimately of the failure of those theories. ${ }^{17}$ But why not instead interpret Marx's changes of position as a part of a process of theoretical refinement, or as fitting responses to changing socio-economic circumstances (the Grundrisse was written in the wake of a severe global economic crisis which raised his revolutionary hopes but which by the 1860 s had passed) $?^{18}$ Moreover, the change in this particular case is not as stark as Stedman Jones implies, for the 'counteracting influences' are also present, in theory if not in name, in the Grundrisse. ${ }^{19}$

The supposed failure of Marx's critique of political economy is a consistent theme that runs through Karl Marx, and for Stedman Jones it is illustrated by Marx's inability to complete Capital. But his interpretations of Marx's work, especially his economic theory, are often questionable. We can use his analysis of the Grundrisse as an illustration. We are told that '[t]he story narrated in what later became the Grundrisse was that of man's loss and historical recuperation, of his "social" or "human nature"', tracing 'the breakdown of man's original sociality to its restoration at the end of the process' ${ }^{20}$ This took the form of a critique of political economy in which Marx adapted Ricardo's labour theory of value, using it to establish that the apparently 'equal' exchange between capital and labour is in reality exploitative and that, because of the falling rate of profit, capital faces repeated and deepening crises. But, according to Stedman Jones, Marx's theory is defective, primarily because of flaws and obscurities in his treatment of value. Although Ricardo had claimed that value was determined by socially necessary labour time, he 'was quite happy to qualify substantially' this claim by acknowledging that 'this no longer held when commodities were produced with unequal amounts of fixed and circulating capital' ${ }^{21}$ Stedman Jones argues that Marx, having initially ignored Ricardo's qualification altogether, decided that it did not pose a challenge to the labour theory of value, because it showed only that prices deviated from value and not that value deviated from socially necessary labour time. But, having in effect therefore conceded that prices are not determined by socially necessary labour time, Marx could sustain the labour theory of 
value only by conflating 'Ricardo's tentative [and qualified] proposition that socially necessary labour time determined equilibrium price' with the very different proposition that only labour creates value. ${ }^{22}$ In identifying labour as the common property which allows commodities to exchange, Marx 'arbitrarily ruled out' other possible properties (such as utility) in order to 'single out his pre-chosen solution'. ${ }^{23}$

In my view, Stedman Jones's summary of the Grundrisse conceals more than it reveals. For instance, one could (with Stedman Jones) say that Marx's choice of labour as the common property of exchange values is 'arbitrary' - but only if we admit that it would be just as arbitrary to choose utility instead! As very many defenders of Marx have argued, the test is not whether labour is a nonarbitrary choice, but whether that choice can generate further arguments with explanatory power. ${ }^{24}$ The problem is not that Stedman Jones is critical of Marx, but that he presents as definitive criticisms which are debatable and often highly dubious and to which many generations of Marxists have offered responses.

The account of Marx's encounter with Ricardo is at best partial and confusing. Stedman Jones seems to think that Marx either ignores Ricardo's qualifications and equivocations or views them as an inconvenience that he can easily brush aside. But it is more accurate to say that Marx fully recognises the problems in Ricardo and uses those problems as the starting point for the elaboration of his own theory of profit. To understand this, we will need briefly to rehearse Ricardo's approach. Why is it that Ricardo argues that different ratios of fixed and circulating capital affect prices (and hence qualify his labour theory of value)? Two assumptions lead him to this claim. First, he believes that wages and profits are inversely related - that is, profits fall as wages rise. Given this, wage rises will have differential effects on profit rates in different industries: profits will fall more sharply in labour-intensive industries (that is, those that employ a greater proportion of 'circulating capital') than in capital-intensive industries (those that employ a greater proportion of 'fixed capital', hence in which wages form a relatively lower proportion of total capital). But, second, Ricardo also believes that there is a general rate of profit (because capital moves between different branches of production until rates of profit are equalized). If there is to be a general rate of profit, however, then as wages rise, the prices of goods produced in capital-intensive industries will have to fall, in order to offset their relatively higher rates of profit (or prices in labour-intensive industries will rise in order to offset their relatively lower rates of profit). Hence, Ricardo concludes that prices are determined by different ratios of fixed and circulating capital and not only by socially necessary labour time. ${ }^{25}$

Ricardo further argues that wages do indeed tend to rise, because falling productivity in agriculture leads to higher food prices and thence higher wages, and so there is a corresponding tendency for the average rate of profit to fall. Therefore - and one would not know this from 
reading Stedman Jones - when Marx states that the tendency of the rate of profit to fall is a law that 'has never been grasped and still less has it been consciously formulated', ${ }^{26}$ what he means is not that this tendency has never before been recognised, but rather that is has been poorly understood. Not only Ricardo, but also Adam Smith before him, noted that the rate of profit tends to fall, but Marx found their explanations trivial or misguided. ${ }^{27}$ Because Ricardo ultimately roots the falling rate of profit in deteriorating soil fertility (because it is this which causes agricultural productivity to decline, causing rising wages and thence falling profits), Marx sardonically observes: 'From the sphere of political economy [Ricardo] flees into organic chemistry'. ${ }^{28}$ Moreover, Marx argues, Ricardo is mistaken in thinking that there is an inverse relationship between wages and profits: if we distinguish profit from surplus value (as Marx does), then it can be seen that the falling rate of profit goes hand in hand with the increasing exploitation of workers (because the profit rate falls as the proportion of constant to variable capital increases, which is identical to increasing productivity and the growth of surplus labour relative to necessary labour). ${ }^{29}$ As Marx states in Capital Volume Three: 'The tendency of the rate of profit to fall is bound up with a tendency of the rate of surplus value to rise, hence with a tendency for the rate of labour exploitation to rise. Nothing is more absurd, for this reason, than to explain the fall in the rate of profit by a rise in the rate of wages'. ${ }^{30}$

Marx therefore resolves the tension in Ricardo's work between the labour theory of value (the claim that the value of commodities is determined by socially necessary labour time) and the assumption that there exists a general rate of profit (which entails that commodities do not always sell at their values). He does so by developing an increasingly sophisticated and complex theory in which labour is distinguished from labour-power, the source of surplus value identified, and surplus value is distinguished from profit. Given that a very significant proportion of the Grundrisse is dedicated to the development of the theory of surplus value, it seems to me absurd for Stedman Jones to claim that ' $[\mathrm{t}]$ he idea of surplus value... was no more than a piece of unsupported speculation, a single paragraph in an 800-page manuscript' ${ }^{31}$

All this is to say that the critique of Ricardo and the elaboration of Marx's theory of value that we find in the Grundrisse are more subtle and sustained that Stedman Jones allows. That theory does, of course, raise significant difficulties and questions. For example, it is the demonstration that prices divert from values that produces the so-called 'transformation problem'. But, again, Stedman Jones proceeds as if these difficulties are fatal for Marx's argument rather than the starting-point for further debates and developments. We are given, for instance, an allusive reference to the 'fundamental criticism[s]' of Böhm-Bawerk, without any acknowledgement of the many rejoinders that Marxists have given to Böhm-Bawerk. ${ }^{32}$ 
Even the claim that the Grundrisse tells a story of 'restoration' or 'recuperation' of an original human nature is misleading. There is restoration of a kind, but of a dialectical kind. Marx explicitly mocks those who wish to restore some lost essence: 'It is as ridiculous to long for a return to that original fulness as it is to believe that the present complete emptiness must be permanent' ${ }^{33}$ The story of Grundrisse is rather that of a progressive development: as 'a system of universal relations, universal requirements and universal capacities', capitalism overcomes the relations of personal dependence found in earlier societies and creates the conditions for the development of communism as a system of '[f]ree individuality, based on the universal development of... individuals' ${ }^{34}$ Indeed, If the Grundrisse can be criticised, it is not for an alleged yearning for the return of a distant past but for the relative crudeness of its dialectical vision, with history moving from an original undifferentiated unity (the subordination of individuals to the community in precapitalist societies) through differentiated disunity (competitive individualism within an alienated community under capitalism) to differentiated unity (collective control of the means of production and the flourishing of the individual under communism).

Stedman Jones argues that Marx's economic theory is not just flawed but reductive, because it marginalises and even obliterates any potential political analysis. This, of course, is a common and longstanding critique of Marx, namely that he is an economic reductionist who cannot account for politics, or at the very least who failed to offer a systematic theory of politics or the state. As Stedman Jones puts it, Marx had a persistent 'difficulty in according any independence to the political sphere'..$^{35}$ (This specific formulation of the objection is made in relation to the Eighteenth Brumaire, which seems especially odd given the frequency with which that text is proffered as evidence of the sophistication of Marx's approach to politics.) I have never found this criticism of Marx very convincing: to the contrary, one of his main strengths is precisely his demonstration that politics and economics are necessarily intertwined. The basic aim of his critique of political economy is to show that the 'economy', which the classical political economists had conceptualised as a natural realm of spontaneous and harmonious interaction between individuals, is in reality structured by political relations of struggle and domination. Hence nothing is ever purely economic or political, and neither politics nor economics are independent of each other. (And so the demonstration in Part VIII of Capital Volume One that capitalism required the political intervention of the state in order to come into being is not, as Stedman Jones seems to think, some kind of concession or retreat by Marx but is perfectly consistent with his critique of political economy as it developed from $1857 .{ }^{36}$ )

For Stedman Jones, it is a symptom of Marx's marginalisation of politics that he consistently misread the political developments and events of his own time. In particular, he failed to appreciate 
the novelty and significance of mid- and late-19th struggles for suffrage. The working classes (Stedman Jones argues) were motivated not so much by economic exploitation as by political exclusion: they sought political reform more than social revolution. Conceiving of 'class as a purely social phenomenon', Marx was slow to understand these new demands. ${ }^{37}$ In contrast, those who were not preoccupied with production or obsessed with the French revolution were able to formulate and pursue forms of politics that were more modest, flexible, and practical. ${ }^{38}$

But were political inclusion and representation ends in themselves or were they sought in the pursuit of other aims, such as the alleviation of poverty or the elimination of exploitation? If the latter, then to what extent did political representation lead to economic justice? Stedman Jones argues that "the political and extra-constitutional significance of the "class struggle", as it had been invoked by the Manifesto, faded away' after 1848, as 'the working classes were progressively reincorporated back into the political system ${ }^{\prime 39}$ But this raises more questions than it answers. Did class struggle continue in other forms? If it 'faded away', was that because all grievances had been satisfactorily resolved, or because the ruling classes were successful in containing and defusing discontent? It seems to me rather complacent to suggest that the working classes have ever been incorporated into the political system, if by that we mean given genuine political power. Even if democratic reforms were the aim of nineteenth-century struggles, this only invites the crucial Marxian question: can purely 'political' rights and freedoms be realised without further social or economic liberation?

Stedman Jones suggests that Marx's preference for revolution over reform is matched by another typically Continental vice: an indulgence of abstraction. Especially after 1845, Marx began to rely on a set of concepts that were 'more abstract and possessed less explanatory power' than the figures of his early writings; imposing his own theoretical framework on events, he produced analyses that ignored the complexities of empirical reality. ${ }^{40}$ Stedman Jones is correct to say that Marx's early critique of abstraction 'was to remain an important and recurrent theme throughout his subsequent work', such that it was a 'central element in his "critique of political economy"', ${ }^{41}$ For example, in the Grundrisse (which is the first expression of Marx's mature economic theory) it is claimed that under the capitalist mode of production 'individuals are now ruled by abstractions' ${ }^{42}$ But there is another use of 'abstraction' in Marx's work. In the 'Introduction' to the Grundrisse, he argues that we can only grasp real, 'concrete' phenomena by using 'the correct scientific method', which begins from abstract relations and determinations and from them ascends to the concrete. Although the empirical reality of the world is 'the starting point of perception and conception', we can only reproduce the concrete in thought through the use of abstractions (such as the concept of 'value') ${ }^{43}$ If we try simply to do away with abstractions in order to apprehend concrete, empirical 
reality immediately and directly then we will only end up with worse abstractions: empty, abstract categories that do not allow us to grasp the concrete as 'a rich totality of many determinations and relations'. ${ }^{44}$

From this perspective, the problem with The German Ideology (or the manuscripts later named as such) is not that it is too abstract, but rather that it too quickly abandons or denounces abstraction in order to return to 'real premises' which can be 'verified in a purely empirical way'. ${ }^{45}$ It is a shame that Stedman Jones has almost nothing to say about Marx's later understanding of abstraction, and very little about the 1857 'Introduction', which is surely the most significant methodological text in Marx's oeuvre.

None of this is to say that Marx was always a faultless interpreter of contemporary events: clearly he was not. But the standard to which Stedman Jones's approach holds Marx is arguably unfair. His aim is to 'treat [Marx's] writings as the interventions of an author within particular political and philosophical contexts that the historian must carefully reconstruct ${ }^{4}{ }^{46}$ But there is a sense in which Stedman Jones, as a historian with access to an enormous array of sources and data, can have a better understanding of, or grander perspective on, that context than Marx. Texts like The Eighteenth Brumaire or The Civil War in France were in effect pieces of journalism: that is, they were preliminary responses to fast-moving and complex events, and so it is no surprise that they can sometimes seem to us, with the benefit of hindsight, naïve or misguided. It also true that there is a strong element of wish-fulfilment in many of Marx's writings, but that is surely forgivable given that, as Stedman Jones says, Marx viewed his works as interventions rather than simply reflections: they were attempts not merely to record what had happened but to bring a new reality into being by inspiring further action.

There are further problems with Stedman Jones's methodology. Reconstructing the political and intellectual context within which a thinker worked can help to disclose how different the past was from the present. But it can also obscure the ways in which a thinker differed from his own present - that is, the ways in which he differed from his contemporaries, and hence the extent to which he brought something genuinely novel into the world. If a thinker like Marx still interests us and hence merits a 600-page biography - it is because his work exceeded its context and speaks to us in a way that the work of many of his contemporaries no longer does. To take an example: Marx's analysis of human-nature relations was radically innovative, exploring both the interpenetration of human society and nonhuman nature and their partial separation under capitalism. But it is only relatively recently that readers of Marx have begun to appreciate the insight and originality of his work in this area, in part because it is only relatively recently that the question of human-nature relations has become an urgent political concern. ${ }^{47}$ In other words, sometimes the value of Marx 
comes to light precisely when we remove him from his context or think about how he transcended his context.

Stedman Jones styles himself as 'a restorer' whose aim is 'to remove the later retouching and alteration contained in a seemingly familiar painting and restore it to its original state': this means detaching Marx from Marxism, untying his work from the 'posthumous elaborations' of later Marxists. ${ }^{48}$ Aside from the fact that the richness and variety of the Marxist tradition is here reduced to Engels, the Second International, and Soviet Marxism, I am highly doubtful that Stedman Jones's goal is feasible. No doubt it is because I am a political theorist rather than a historian that I am more interested in how we can use Marx today than in returning him to the past. But even if I thought it desirable to return to an original Marx, I am not convinced that it would be possible. The texts that are brought under the name 'Marx' are inseparable from their reception - both before and after Marx's death. As such, the contexts within which Marx's work needs to be placed are those of its production and its reception.

Any reading of Marx will necessarily be informed by both existing interpretations and by present-day considerations. Stedman Jones himself reads Marx in the light of current concerns and trends: his assessment of Marx is in part based on the extent to which Marx's insights have subsequently been vindicated or superseded. Marx is praised for contributing to the formation of a social-democratic idiom that is still in use. Conversely, his supposedly reductive conception of class is rejected as outdated: 'historians have come to understand class no longer as the expression of simply socio-economic reality, but as a form of language discursively produced to create identity'.$^{49}$ Both of these judgments reflect Stedman Jones's own interests and preferences as developed and expressed in earlier works: his belief that we should seek to reform capitalism rather than vainly agitating for its overthrow, and his contention that language plays a constitutive role in structuring our experiences of class. ${ }^{50}$ But these interests and preferences are themselves deeply rooted in particular contexts, and are showing their age: the discursive approach to class was a product of the 1980s' Anglophone reception of French post-structuralism, which has lately come under challenge from a 'materialist turn' that includes the recent revival of Marxist political economy; ${ }^{51}$ and the trust in market-friendly varieties of social democracy is a product of post-Cold War complacency and late1990s Blairite optimism that has seemed less certain, and less attractive, since the 2008 financial crisis. Thus, after reading this biography, I was left with the sense that it is the author, rather than its subject, who is behind the times. Faced with the threats of economic turbulence, deepening inequality, growing authoritarianism, and potential ecological catastrophe, Marx's prognosis - that class struggle will end 'either in a revolutionary re-constitution of society at large, or in the common 
ruin of the contending classes' ${ }^{52}$ - seems less unrealistic than Stedman Jones's contention that capitalism can be tamed and reformed. 
Bibliography

Burkett, Paul. Marx and Nature: A Red and Green Perspective. Chicago, IL: Haymarket Books, 2014.

Choat, Simon. Marx's Grundrisse: A Reader's Guide. London: Bloomsbury, 2016.

Cohen, G. A. History, Labour, and Freedom: Themes from Marx. Oxford: Clarendon Press, 1988.

Coole, Diana, and Samantha Frost. 'Introducing the New Materialisms.' In New Materialisms:

Ontology, Agency, and Politics, edited by Diana Coole and Samantha Frost. Durham, NC: Duke University Press, 2010.

Ehrbar, Hans, and Mark Glick. 'The Labor Theory of Value and Its Critics.' Science \& Society 50, no. 4 (1986): 464-78.

Foster, John Bellamy. Marx's Ecology: Materialism and Nature. New York, NY: Monthly Review Press, 2000.

Heidegger, Martin. Basic Concepts of Aristotelian Philosophy. Translated by Robert D. Metcalf and Mark B. Tanzer. Bloomington, IN: Indiana University Press, 2009.

Marx, Karl and Frederick Engels Collected Works, 50 vols. London: Lawrence \& Wishart, 1975-2005.

McLellan, David. Karl Marx: A Biography. Basingstoke: Palgrave Macmillan, 2006.

Mehring, Franz. Karl Marx: The Story of His Life. Translated by Edward Fitzgerald. London: George Allen \& Unwin, 1966.

Padover, Saul K. Karl Marx: An Intimate Biography. New York, NY: McGraw- Hill, 1978.

Reuten, Geert, and Peter Thomas. 'From the "Fall of the Rate of Profit" in the Grundrisse to the Cyclical Development of the Profit Rate in Capital.' Science \& Society 75, no. 1 (2011): 74-90.

Ricardo, David. On the Principles of Political Economy and Taxation. Edited by Piero Sraffa. Cambridge: Cambridge University Press, 1951.

Leopold Schwarzschild. The Red Prussian: The Life and Legend of Karl Marx. New York, NY: Charles Scribner's Sons, 1947.

Smith, Adam. An Inquiry into the Nature and Causes of the Wealth of Nations. Oxford: Clarendon Press, 1976.

Spargo, John. Karl Marx: His Life and Work. New York, NY: B. W. Huebsch, 1910.

Sperber, Jonathan. Karl Marx: A Nineteenth-Century Life. New York, NY: Liveright, 2013.

Stedman Jones, Gareth. 'All that's left is reformism.' The Guardian, August 12, 2002.

https://www.theguardian.com/politics/2002/aug/12/comment. Accessed July 6, 2017.

Stedman Jones, Gareth. Karl Marx: Greatness and Illusion. London: Allen Lane, 2016. 
Stedman Jones, Gareth. Languages of Class: Studies in English Working Class History 1832-1982.

Cambridge: Cambridge University Press, 1983.

Tomba, Massimiliano. 'Accumulation and time: Marx's historiography from the Grundrisse to Capital.' Capital \& Class 37, no. 3 (2013): 355-72.

Wheen, Franics. Karl Marx. London: Fourth Estate, 2000.

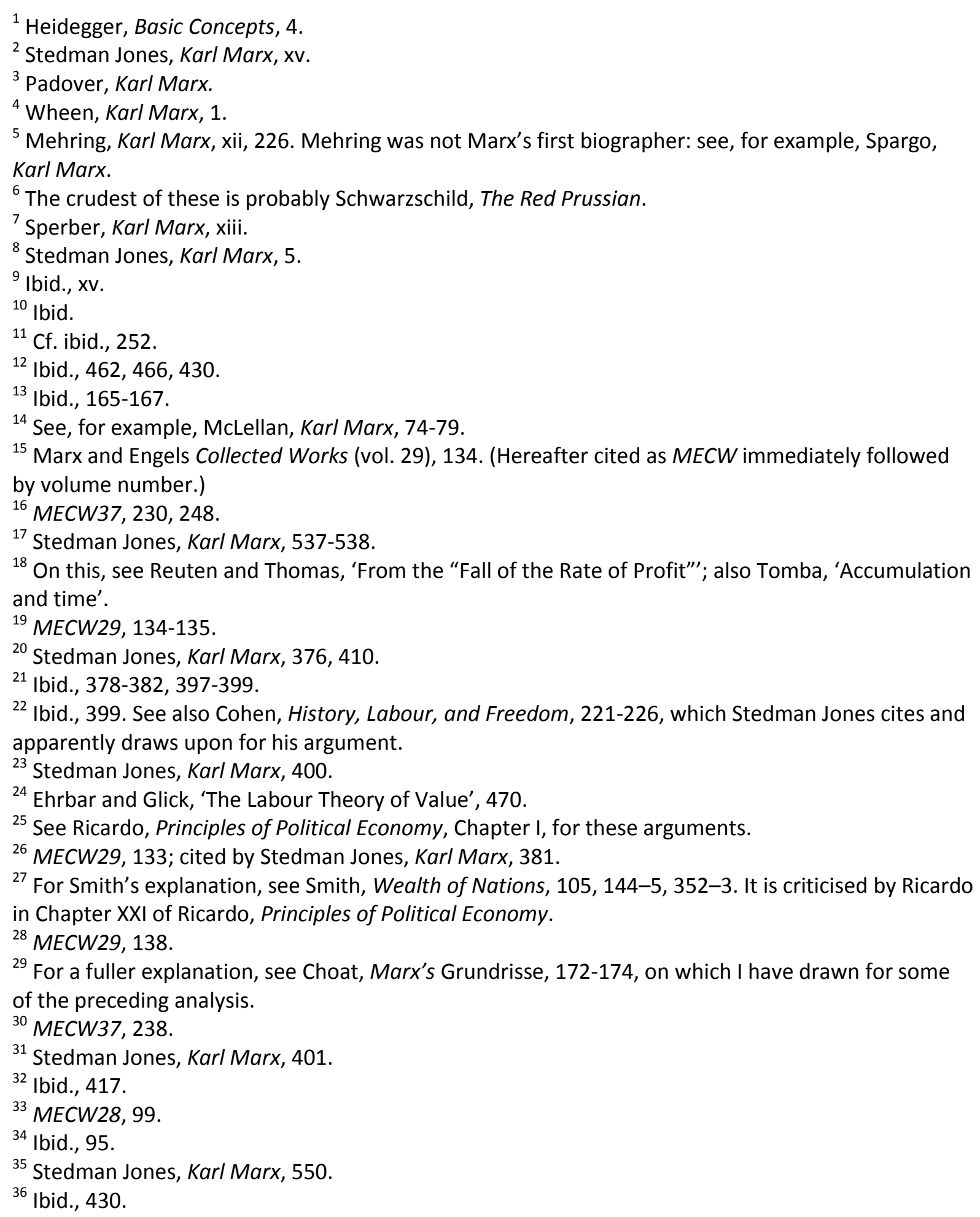


${ }^{37}$ Ibid., 486.

${ }^{38}$ Ibid., 396-397.

${ }^{39}$ Ibid., 313.

${ }^{40}$ Ibid., 234.

${ }^{41}$ Ibid., 193-4.

${ }^{42}$ MECW28, 101

${ }^{43}$ Ibid., 38.

${ }^{44}$ Ibid., 37.

${ }^{45}$ MECW5, 31.

${ }^{46}$ Stedman Jones, Karl Marx, xv.

${ }^{47}$ Two of the best examples are Foster, Marx's Ecology and Burkett, Marx and Nature.

${ }^{48}$ Stedman Jones, Karl Marx, xv, 5.

${ }^{49}$ Ibid., 306.

${ }^{50}$ See especially Stedman Jones, Languages of Class. His belief in reformism is concisely expressed in Stedman Jones, 'All that's left'.

${ }^{51}$ See for example Coole and Frost, 'Introducing the New Materialisms'.

${ }^{52}$ MECW6, 482 